\title{
New finds of skeletal fossils in the terminal Neoproterozoic of the Siberian Platform and Spain
}

Andrey Yu. Zhuravlev, Eladio Liñán, José Antonio Gámez Vintaned, Françoise Debrenne, and Aleksandr B. Fedorov

Acta Palaeontologica Polonica 57 (1), 2012: 205-224 doi: http://dx.doi.org/10.4202/app.2010.0074

A current paradigm accepts the presence of weakly biomineralized animals only, barely above a low metazoan grade of organization in the terminal Neoproterozoic (Ediacaran), and a later, early Cambrian burst of well skeletonized animals. Here we report new assemblages of primarily calcareous shelly fossils from upper Ediacaran (553-542 Ma) carbonates of Spain and Russia (Siberian Platform). The problematic organism Cloudina is found in the Yudoma Group of the southeastern Siberian Platform and different skeletal taxa have been discovered in the terminal Neoproterozoic of several provinces of Spain. New data on the morphology and microstructure of Ediacaran skeletal fossils Cloudina and Namacalathus indicate that the Neoproterozoic skeletal organisms were already reasonably advanced. In total, at least 15 skeletal metazoan genera are recorded worldwide within this interval. This number is comparable with that known for the basal early Cambrian. These data reveal that the terminal Neoproterozoic skeletal bloom was a real precursor of the Cambrian radiation. Cloudina , the oldest animal with a mineralised skeleton on the Siberian Platform, characterises the uppermost Ediacaran strata of the Ust'-Yudoma Formation. While in Siberia Cloudina co-occurs with small skeletal fossils of Cambrian aspect, in Spain Cloudina-bearing carbonates and other Ediacaran skeletal fossils alternate with strata containing rich trace fossil assemblages. These finds treated together provide a possibility to correlate transitional Neoproterozoic-lower Cambrian strata around the world. Such a correlation concurs with available isotope and radiometric data and indicates that typical Ediacaran shelly fossils have not crossed the Precambrian-Cambrian boundary.

Key words: Cloudina, Ediacaran skeletal fossils, Siberian Platform, Spain.

Andrey Yu. Zhuravlev [ayzhur@mail.ru] and Eladio Liñán [linan@unizar.es], Área y Museo de Paleontología, Departamento de Ciencias de la Tierra, Facultad de Ciencias, Universidad de Zaragoza, c/Pedro Cerbuna, 12, E-50009, Zaragoza, Spain; José Antonio Gámez Vintaned [J.Antonio.Gamez@uv.es], Departamento de Geologia, Universitat de Valencia, c/Dr. Moliner, 50, E-46100, Burjassot, Spain; Françoise Debrenne [francoise.debrenne@neuf.fr], rue du Long Foin 13, Sainte Genevièvedes- Bois, F-91700, France; Aleksandr B. Fedorov, Siberian Scientific-Researching 
Institute of Geology, Geophysics and Mineral Resources, Krasniy prospekt 67, Novosibirsk 630104, Russia.

This is an open-access article distributed under the terms of the Creative Commons

Attribution License (for details please see creativecommons.org), which permits unrestricted use, distribution, and reproduction in any medium, provided the original author and source are credited.

FoF Full text $(1,311.3 \mathrm{kB})$ 